\title{
The Equation of Life in the East India Company Armies: Statistical Arguments for the provision of Private Pensions
}

\author{
Philip Talbot \\ Birmingham City University, Department of Accounting and Finance, Business School, England, UK \\ Correspondence: Philip Talbot, Birmingham City University, Business School, City North Campus, Perry Barr, \\ Birmingham, West Midlands, B42 2SU, England, UK. E-mail: philip.talbot@bcu.ac.uk
}

Received: June 24, 2013 Accepted: July 9, 2013 Available online: August 22, 2013

doi:10.11114/ijsss.v1i2.208 URL: http://dx.doi.org/10.11114/ijsss.v1i2.208

\begin{abstract}
The basis for mortality tables that underpin life insurance plans are based on the statistics at each age of mortality. This had first been attempted by the English astronomer Halley in 1692 based on German sources since none were available in Great Britain (Bacaër: 2011). However, the first mortality statistics to be used by insurance companies did not appear until the late eighteenth century with the use of the inaccurate Northampton tables that were extensively used by insurance companies in and outside of Great Britain (Rothschild, 2009). In 1847 a further unique contribution to mortality tables was offered by an ex-officer of the East India Company Army William Henry Sykes who argued for cheaper premiums to be available for the native soldiers and their dependants in India.

Sykes's work is grounded in the prolific statistical movement of the late eighteenth and nineteenth centuries derived from the copious statistics of the East India Company Armies that he had access to as a Company director. This paper seeks to place Sykes's innovative work as an early prominent statistician within his personal military experience and the unique position of the wealthy East India Company a trading company that also grew into a powerful military and naval force.
\end{abstract}

Keywords: statistics, counting, pensions, mortality, living index, equation of life

\section{Introduction}

\subsection{Historical Background}

Counting is perceived as a way of improving the world because mankind believes it can quantify and ascribe a number to anything then it can be controlled. This increasing domination of numbers in modern life has been accused of being "the tyranny of numbers (which) began with the simple counting of things with marks on wood... from 15000 BC". (Boyle, 2001:6). The development and mutation of counting into the political arithmetic of Petty in the seventeenth century described as "the Method of Reasoning by Figures, upon Things relating to Government" (McCormick, 2009:290) and progressed into the latter statistical movement from the eighteenth century onwards. This evidenced a passion for amassing facts which once discovered could be used to reduce uncertainties in numerous fields including occupations, health and sickness. In Britain precise areas and locations of safety and uncertainty within and outside the British Empire, however flawed, were sought through counting and statistical analysis in as far "this form of risk management thus involves the colonisation of time: danger would seem to be plucked out of its hiding place in the invisible reaches of the future and brought into the present, to be experienced, survived and thus eradicated. The idea that risk could be written into, and out of, specific places provided powerful consolation ...for the inhabitants of the tumultuous Victorian moment of modernity". (Freedgood, 2000:1).

\subsection{Sykes in Perspective}

A leading exponent amongst these early statisticians was the Englishman Colonel William Henry Sykes who collected detailed facts and applied his analysis to the returns of the British East India Company and its armies of the mid nineteenth century. He did so in order to produce a 'Living Index' or 'Equation of Life' for European and Native troops to argue for the provision of cheap private life insurance for the latter and at the same time 
dispel negative European presumptions about Indian troops. In essence Sykes performed an early form of life insurance risk assessment for insurance actuaries.

This paper will outline Sykes's path to prominent statistician status and how he assembled and analysed his data to support his arguments by contextualising his work within the early development of statistics. It will also chronicle Sykes long and formative statistical relationship with the East India Company inside the development of this new intellectual disciplinary movement.

\section{Numbers, Control and Risk}

\subsection{The Chronology of Statistics}

The genesis of counting or political arithmetic as it was then known in the modern era in England can be identified as occurring in the late seventeenth century with Gaunt and Petty's (1662) Natural and Political Observations on the Bills of Mortality. This analysed the London mortality rolls which was proposed as the basis for an attempt to create a predictive system to warn of plague occurring though it conspicuously failed to predict the Great Plague of London in 1665. However, this movement was part of a wider European phenomenon by which the Observations reflected sixteenth century French practise whereby government agencies had collected various statistics of the state allowing the counting of subjects that served to measure wealth of the state (Bhimani, 1993:20).

\subsection{The Statistical Movement in Great Britain}

The intensity and breadth of counting increased substantially in the late eighteenth and early nineteenth centuries when counting/political arithmetic became redefined as statistics generically labelled as the 'Statistical Movement'. This arose from W. Hooper's 1770 translation of the German Von Biefelfeld's, The Elements of Universal Erudition whereby statistics was now accorded a scientific status that "teaches the political arrangement of all the modern states and of the known world" (Cullen, 1975: 10). The increasing popularity of German statistics in Great Britain was further enhanced with the publication of T.B. Clarke's (1790) Statistical View of Germany, which was reinforced by Sir John Sinclair's (1791) Statistical Account of Scotland. At the close of the eighteenth century the original German meaning of statistics had again mutated as being defined by The Encyclopaedia Britannica (1797) as, "A word lately introduced to express a view or survey of any Kingdom, county or parish" (Mackenzie, 1981:7).

In Great Britain, this resulted in the widespread collection and counting of eclectic data undertaken by agencies of the state, independent bodies and individuals. Renowned examples of this technique comprised Thomas Malthus's, An Essay on the Principle of Population as it Affects the Future Improvement of Society (1798), Dr Francis Bisset Hawkins's The Elements of Medical Statistics (1829), the social reformer Edwin Chadwick's Poor Law Report (1833), J.R. McCulloch's Statistical Account of the British Empire (1837), Harriet Martineau's Illustrations of Political Economy (1834) and the numerous works of the utilitarian Jeremy Bentham (1748-1832). These types of statistical works exemplified the detailed counting, cataloguing, classification and measurement of data which typified a new emergent thinking which attempted to understand society in terms of numbers and quantification through which it attempted to minimize uncertainty. It became a symptom of the new scientific age, confident that it could control the chaos around it with the unrelenting application of facts and measurements (Boyle, 2001:81). It was within this innovative knowledge system that Sykes's work may be located.

\section{Sykes, (1790-1872)}

\subsection{Sykes Early Career}

The initial career path that eventually led Sykes to becoming a statistician began in 1803 when, just thirteen years old, he joined the Bombay Army of the British Honourable East India Company as an officer cadet most likely in one of the Native Regiments. He participated in the Second Mahratha War (1803-1805) and served at the siege of Bhurtpore between January and April 1805 (Butterfield, 1981) and later at the battle of Kirkee and Poona in the Third Maratha and Pindari War (1817-1818). In 1819 he gained his captaincy and by 1820 Sykes's had amassed a personal fortune the basis of which was never explained. This wealth enabled Sykes to return to Europe for four years' leave, spending his time travelling the continent, pursuing scientific studies and acquiring foreign languages. It was normal practice at the time to award a furlough, usually of a three-year period of leave, to Company officers with ten years' service (Gourvish, 1972: 48-49).

It seems likely that it was during this furlough that Sykes obtained a knowledge and enduring ardour for statistics. In 1824, recently married, he returned to India where Sykes's statistical vocation began when the Lieutenant Governor of Bombay, the Hon Monstuart Elphinstone appointed Sykes as 'Statistical Reporter' to the Bombay 
Presidency. Further promotion followed to the rank of major in 1826, and although the office of Statistical Reporter was abolished in 1829 to secure financial savings Sykes continued to work gratuitously in that role until June 1833. It was during this period that he completed a census of the Deccan, two statistical reports and a catalogue of birds and mammals of the area (Smith Elder and Co, 1885). He subsequently published his natural history that included 56 birds new to science, in the Proceedings of the Zoological Society in 1832, as well as writing other natural history papers.

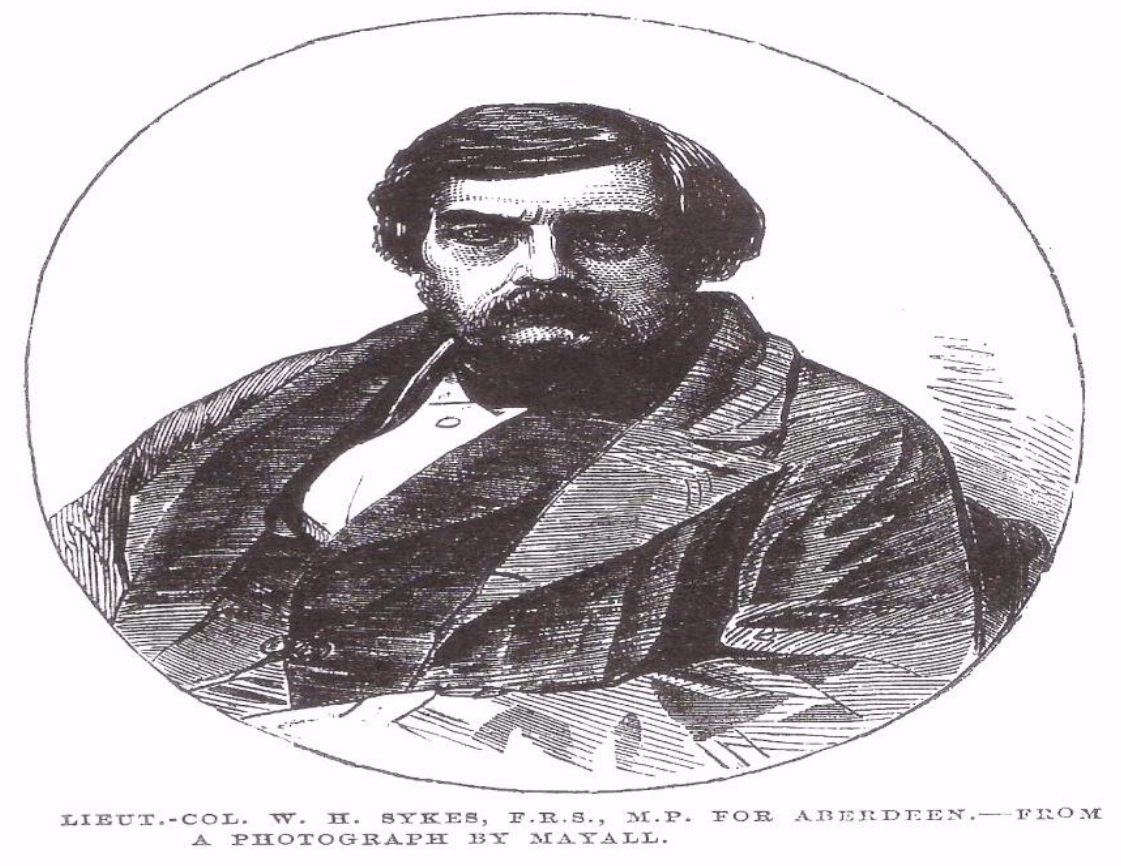

Illustration 1. Lieutenant Colonel William Henry Sykes

London Illustrated News, $23^{\text {rd }}$ May 1857

\subsection{Sykes's Rise to Prominence}

At the age of 42, Sykes retired from the East India Company Army in 1833 with the rank of lieutenant colonel, and returned to England. In 1834, he became a founder member of the Statistical Society of London eventually rising to become president in 1863-65. Monstuart Elphinstone was one of the new society's trustees, and his powerful influence and patronage, coupled with Sykes' natural abilities and talent, may have helped Sykes' advancement in the Society. At the same time he was elected a fellow of the Royal Society of London becoming its chairman in 1858. He is recorded in August 1835 as delivering a paper in Dublin to the British Association for the Advancement of Science (BAAS), Statistical Section known as Section F which had important links with the London Statistical Society. This proved to be of particular interest to a prominent conference delegate Alexis de Tocqueville, the eminent French political thinker and historian as the paper related to the workers and the poor in India, topics that interested Tocqueville. Sykes was at this time the secretary to the BAAS's statistical section (Drolet: 2004: 469).

In the same year he was appointed as one of the unpaid Metropolitan Lunacy Commissioners whose report was instrumental in the passage of the Lunacy Act of 1837. He performed these duties without cause till the reconstruction of the Lunacy Commission in 1845. He also actively promoted the establishment of other provincial statistical societies which were being created across the country at the time and he is recorded in 1837 as encouraging "the propriety of establishing a statistical society in Liverpool" (O'Brien 2011:53). He did not restrict his intellectual activities to statistics but also wrote extensively on Indian ornithology and wildlife, geology and culture. He had also become a member and later president of the Royal Asiatic Society.

Sykes as well became active in national politics and after being initially defeated in 1847 as the prospective candidate for Aberdeen he successfully contested the seat in 1857 being returned as the Liberal Member of Parliament a position he held until his death. This unexpected link with Scotland probably arose from his wife 
Elizabeth's family the Hay's hailing from Renistoun in Scotland. Prior to this in 1854 he had been elected lord rector of the Marischal College, Aberdeen.

Yet this was not all as Sykes was also a corporate executive of the East India Company because his extensive knowledge of Indian affairs led to him being elected in 1840 to the board of directors of the Company, of which he became deputy chairman in 1855 and its last ever chairman in 1856.

Truly, Sykes was a busy man and he explained his own character thus,

"I am so much of a utilitarian, that I am disposed to view labour, both mental and physical, that has not some practical object - some definite view- some proximate or remote applicability to the use of the community or to individuals-as labour lost, or, at the least, misapplied ..."

(Sykes, 1847:118)

\subsection{Sykes Criticised}

Nonetheless, this apparent paragon of utilitarianism was not without criticism. Mrs Mary Meredith writing in 1856 about a rival candidate to her husband George (an English novelist and poet) for an administrative post within the Society of Arts in London observed, “... I have no doubt he (the rival candidate) will be the pet of Dr Booth and Colonel Sykes, who I am sorry to see, is now chairman: he is regarded as a tremendous bore at the E.[ast] I[ndia] H[ouse] and my father detests him" (Joukovsky, 2000:480). Her father was Thomas Love Peacock also a novelist and poet who had worked as one of the two senior administrators at the East India Company headquarters from 1819-1852 and would have known Sykes well. Peacock recorded his less than onerous time there in his poem, "A Day at the India Office",

"From ten to eleven, have breakfast for seven;

From eleven to noon, think you've come too soon;

From twelve to one, think what's to be done;

From one to two, find nothing to do;

From two to three, think it will be

A very great bore to stay till four."

(Joukovsky, 2000:474-475).

Peacock's strong dislike of Sykes is evident when post-retirement he wrote to Lord Broughton in 1856 that he did not miss his former occupation with the Company and that, "...I should find ample compensation in having nothing to do with the Artium Societatis Socius (Sykes), who is present in the chair." This was a reference to an old joke concerning Doctor Pangloss's self congratulation on his admission to the Society of Arts (Joukovsky, 2000:492, ftn52). This demonstrated an attitude at complete odds with that of the work driven Sykes. It was this utilitarian zeal and capacity for statistical analysis that Sykes brought to bear on the East India Company Armies which he knew intimately.

\section{The East India Company and Its Armies}

\subsection{The Trading Company}

In order to understand Sykes's work it is first necessary to place it within context since as at first sight it appears peculiar and unique that a commercial company should retain its own extensive military and naval forces rather than the state.

The East India Company was founded by royal charter granted in 1600 and was originally named 'The Governor and Company of Merchants of London Trading in the East Indies' and after merging in 1709 with the Levant Company trading in the East it became 'The United Company of Merchants of England trading to the East Indies'. It was organised as a joint-stock association of English merchants who received, by a series of charters, exclusive rights to trade to the 'Indies' meaning those territories lying between the Cape of Good Hope and the Straits of Magellan establishing trading outposts or factories in south and East Asia. Its cumbersome name remained its legal title until 1874 (when its affairs were eventually wound up) but from the passage of the Charter Act of 1833 it became habitually referred to as the East India Company in most parliamentary documents and debates. Occasionally it was referred to as the "Honourable Company" but it was more often called "John Company". The origins of this latter name are obscure, and may be a reference to 'jehan' meaning powerful in the native Indian tongue (Wild, 1999:7) with India becoming the main base of its territorial power. The widening power and influence of the Company led the British Government in 1784 to institute standing Commissioners, the Board of Control in London to control its civil and military affairs in India (Misra 1959:1). Its expansion and dominance of Indian trade was subject to several commercial setbacks in 1770 and 1784 
secured by government financial rescues. The latter created a Board of Control of six members to include the Chancellor of the Exchequer and Secretary of State both being senior members of the British government who were to direct the Court of Directors (Figure1). As a consequence the Company retained control of its trading monopolies but this witnessed the demise of true independence from government. Even this disappeared with the passage of the Charter Act (1833) which removed the trading monopolies in favour of laissez-faire as this was officially held to be incompatible with ruling. Incongruously the Company was then left to rule India in imperial fashion in a role that it had never been intended to fulfil.

\subsection{The Company Governance and Administration}

This administration of the Company's Indian possessions led to a Company Civil Service (the forerunner of the Indian Civil Service) being created which played a paramount role in fashioning British India (O'Malley, 1931: xi). One of its pre-eminent civil servants was John Mill, the author of Elements of Political Economy (1821), who explained, "...the business, though laborious enough, is to me highly interesting. It is the very essence of the internal government of sixty million people with which I deal"

(Micklethwait \& Wooldridge, 2003:44).

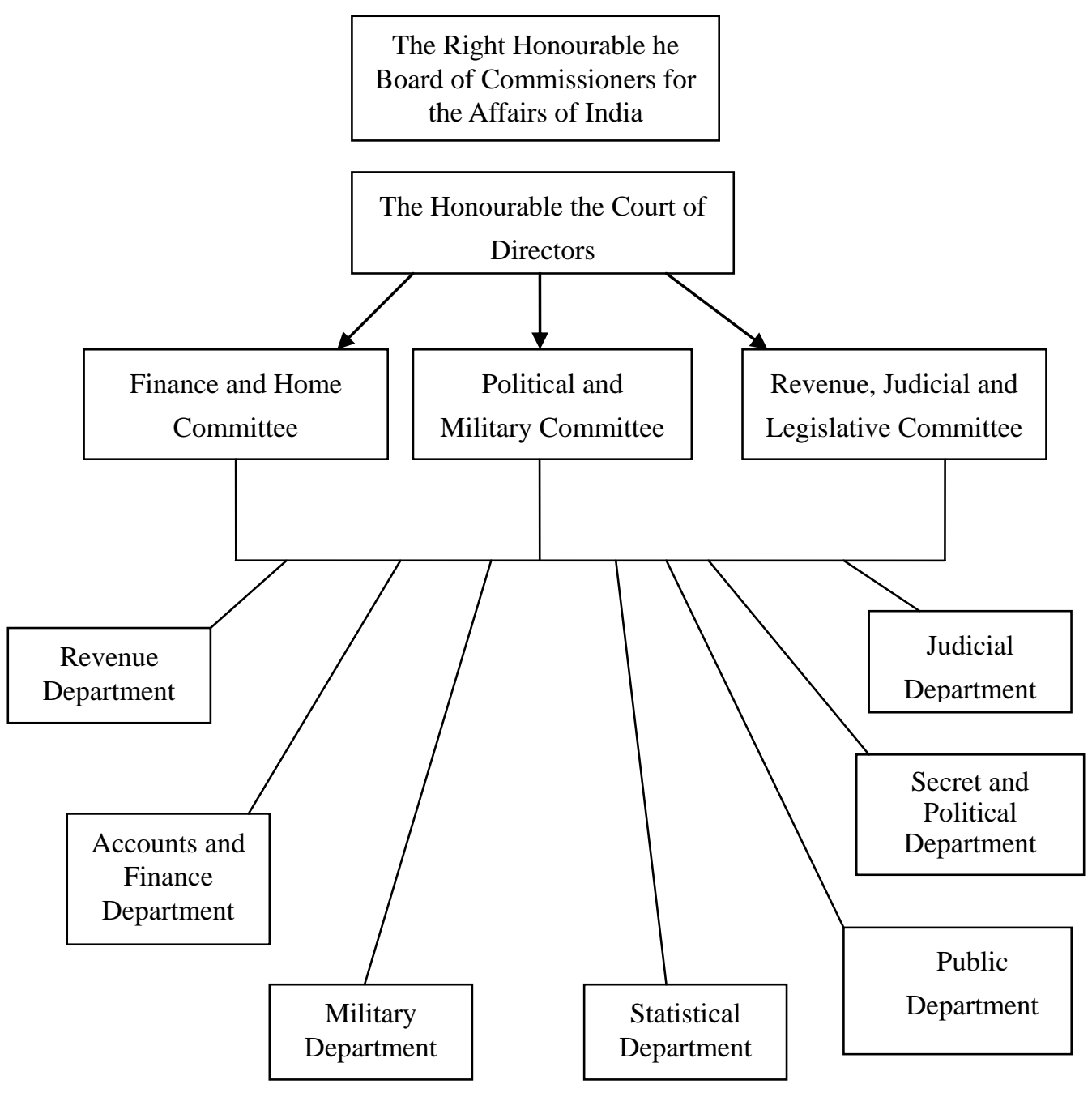

Compiled from Clarke. F, (1847: pxv).

Figure 1. The Company's Home Establishment (India House) 1847

The Company thus remained responsible, under the supervision of the Board, for the government of India until the re-organisation of 1858 in the aftermath of the Indian Mutiny. 
Throughout this period the Company's organisational structure remained largely intact. It consisted of a large body of shareholders, an elected Court of Directors led by a Chairman and Deputy Chairman that Sykes became with a supporting administrative structure of executive officials based in India House near to the Board of Control in the City of London.

\subsection{The Company as a Military and Naval Power}

The Company's position in India inevitably brought it into serial conflict with rival European powers notably the Portuguese, Dutch and French as well as local Indian princes against whom they eventually triumphed. The Company had also been granted by the British government the powers to wage war, and negotiate peace treaties albeit with any non-Christian nation (Dupuy and Dupuy 1999:764) so that they were often allied to local Indian princes. This arrangement admirably suited the British government because it relieved it of the large expense of defending India, (the Company baring most of the cost) although it did provide small contingents of regular Crown troops, which permitted it to influence military operations by proxy. Nonetheless, the extraordinary position was that the Company had created three large private armies, administered and paid for by the Company, obeying their own Commander in Chief, which was entirely separate from the regular British Army. At its zenith the Company's Armies based on the three separate administrative Presidencies of Bengal, Bombay and Madras amounted to 250,000 men of which only 45,000 were European officers and ranks (Wild, 1999:132). Thus, "for nearly half a century after the collapse of Napoleon's grande arme'e in 1813, the army of the East India Company was probably the world's largest. Native sepoy recruits accounted for the bulk of the Company's forces..." (Mokyr and O'Grada, 1996:141). It had also become a naval power in its own right so that by 1857 the Company's fleet consisted of 43 warships and 273 European Officers (Wild, 1999:54).

It was in the Bengal Army the most important of the three Company Armies that Sykes served. The reasons for Sykes being entered for a Company military career remain obscure since there are no ostensible family links for service, and a commission in the Company's service was always held to be socially inferior to that of a Crown commission, and could often be regarded as disreputable. The Company's European officer corps at this time was notoriously undisciplined, having arrested their Governor-General (who subsequently died in their custody) in 1776 in reprisal for his ordering the arrest of the army Commander-in-Chief who had been accused of inciting his troops to mutiny. A more serious mutiny occurred later in the Madras Army during Sykes's era, in an event dubbed 'The White Mutiny' in 1809, which led to 21 officers being court-martialled, cashiered or dismissed before order was restored. This incident was deliberately obscured by the authorities in order to preserve stability (Cardew, 1929).

\section{The Statistical Analysis of the East India Company's Army Pension Establishment}

\subsection{The Company Armies Statistical Data}

In approximately 1847 Sykes composed the first of his two military analysis papers for the Statistical Society entitled The East India Company's Armies in India: European and Native. (Endnote 1). The second military paper devoted to comparing the French and British army's followed much later in 1864 (Talbot, 2005) and his statistical methods endured until the early twentieth century in some military circles and in industry (Talbot, 2010). At this time he was Vice-President of the Royal Society and a Company director being Chairman of the Political and Military Committee which would have allowed him privileged access to the military data (Clark, 1847: xvi).

The raw data for Sykes's analysis arose from the Company's army's returns to the Company's Military Auditor General relating to the Pension Establishments of the Native Armies of the three Presidencies. Sykes was aided and abetted in the preparing the analysis by “...our valuable coadjutor, Mr Neison, who with that indefatigable perseverance love of his subject, and readiness to oblige, of which he has already given us so many proofs, has laboriously worked out for me the tables for which I have to notice. (Sykes1847: 100). It should be emphasised here that Sykes analysis is focusing on the Indian not the European (British) pension establishment. The European officer corps and ranks had their own separate pension establishment of which Sykes was member. As a lieutenant colonel he was entitled to $£ 20015$ s 0d annually or eleven shillings a day (Clark, 1847).

As Sykes explained the Company's Army returns formed part of the periodical statistical returns which were not always entirely accurate made from each of the three Presidencies to India House, Military Department at the Company's main office in London although the use of this data is not rendered explicit. The paper was arranged in three sections, the first being the "Vital Statistics of the Bombay Native Army, at every age from 20-52 for the years 1842, 1843 and 1844". The second section dealt with "The Vital Statistics of the Indian Army, European and Native, from 1825-1844, both inclusive" and the final third section dealt with the "Vital Statistics of the 
Pension Establishments of the Native Armies of the Three Presidencies". These were analysed by twenty two separate and detailed tables.

\subsection{The Company's Armies Mortality Rates; Statistical Tables}

This paper deals with the pension analysis as the first and second parts have been dealt with previously elsewhere (Talbot, 2008). However, a brief summary of this analysis concluded that the health of the Native troops was superior to the European troops because they benefitted from a better diet, consumed much smaller quantities of spirits and alcohol and possessed greater mental vacuity. The overall Native pension establishment comprised three separate elements, i.e. the Pension Establishment, the Family Pension Establishment and the Wound Pension and was separately operated for the three different Company Presidency Armies, i.e. Bengal, Madras and Bombay. This paper will focus on the Bombay army alone because Sykes used this official data to calculate innovative tables presenting an 'Equation of Life' or 'Living Index'. The absolute mortality of the Bombay Army at every age from 21 to 52 was presented in a table for 1842, 1843 and 1844 and percentages calculated in a separate table. These were then used calculate a mean mortality per cent given in Table 1 below. This first official data had originally been drawn up by Military Auditor in Bombay to identify the health effects of troops serving in Scinde province. Sykes explained that he thought that these "... returns of this kind are unique, whether relating to the India Company's Army or the Royal troops serving in India." (Sykes 1847:100)

Table 1. Mean Mortality per Cent of the Bombay Army for 1842, 1843, 1844

\begin{tabular}{cccccccc}
\hline Ages & Living & Deaths & Mortality Per cent & Ages & Living & Deaths & Mortality Per cent \\
\hline 21 & 18131 & 540 & 2.9873 & 37 & 2989 & 66 & 2.2081 \\
22 & 8761 & 196 & 2.2371 & 38 & 2710 & 83 & 3.0627 \\
23 & 9050 & 202 & 2.2320 & 39 & 2225 & 60 & 2.6966 \\
24 & 8109 & 217 & 2.6760 & 40 & 2172 & 73 & 3.3610 \\
25 & 6549 & 178 & 2.7180 & 41 & 1760 & 39 & 2.2159 \\
26 & 4946 & 121 & 2.4464 & 42 & 1431 & 40 & 2.7953 \\
27 & 3783 & 95 & 2.5112 & 43 & 1429 & 51 & 3.5689 \\
28 & 2455 & 90 & 3.6660 & 44 & 1234 & 38 & 3.0794 \\
29 & 1778 & 52 & 2.9246 & 45 & 1069 & 37 & 3.4612 \\
30 & 1378 & 48 & 3.4833 & 46 & 844 & 24 & 2.8436 \\
31 & 1094 & 25 & 2.2852 & 47 & 689 & 26 & 3.7736 \\
32 & 1258 & 29 & 2.3052 & 48 & 645 & 23 & 3.5659 \\
33 & 1643 & 42 & 2.5563 & 49 & 481 & 12 & 2.4948 \\
34 & 2102 & 57 & 2.7117 & 50 & 354 & 13 & 3.6723 \\
35 & 2958 & 89 & 3.0088 & 51 & 264 & 10 & 3.7879 \\
36 & 2892 & 80 & 2.7758 & 52 & 745 & 17 & 2.2819 \\
Totals & 76886 & 2061 & & & 21041 & 612 & \\
\hline & & & & & & & $($ Sykes $1847: 103)$
\end{tabular}

This overall profile was then broken down further to distinguish the mortality levels of troops serving in Scinde province compared to those not serving there and against the Bombay army as a whole. Originally these were presented in three detailed tables and for convenience and clarity these have been combined in Table 2 below.

Table 2. Mortality of Bombay Army Regiments serving in Scinde, Not serving in Scinde and overall at each Age with Average for every Fifth Year from 1842-1844

\begin{tabular}{cccccccccc}
\hline Ages & $\begin{array}{l}\text { Population } \\
\text { Scinde* }\end{array}$ & $\begin{array}{c}\text { Deaths } \\
\text { Scinde }\end{array}$ & $\begin{array}{l}\text { Per Cent } \\
\text { Scinde }\end{array}$ & $\begin{array}{l}\text { Popul-ation } \\
\text { not in Scinde }\end{array}$ & $\begin{array}{l}\text { Deaths not } \\
\text { in Scinde }\end{array}$ & $\begin{array}{l}\text { Per Cent not } \\
\text { In Scinde }\end{array}$ & $\begin{array}{l}\text { Total } \\
\text { Popul-ation }\end{array}$ & $\begin{array}{l}\text { Total } \\
\text { Deaths }\end{array}$ & $\begin{array}{l}\text { Total } \\
\text { Per Cent }\end{array}$ \\
\hline $21-25$ & 15611 & 668 & 4.279 & 34998 & 665 & 1.901 & 50600 & 1333 & 2.634 \\
$26-30$ & 5509 & 233 & 4.229 & 8831 & 173 & 1.959 & 14340 & 406 & 2.831 \\
$31-35$ & 3339 & 129 & 3.863 & 5716 & 113 & 1.977 & 9055 & 242 & 2.673 \\
$36-40$ & 4123 & 201 & 4.875 & 8865 & 161 & 1.816 & 12988 & 362 & 2.790 \\
$41-45$ & 1898 & 94 & 4.953 & 5025 & 111 & 2.209 & 6923 & 205 & 2.961 \\
$46-50$ & 741 & 27 & 3.644 & 2272 & 71 & 3.125 & 3013 & 98 & 3.252 \\
$51-52$ & 141 & 7 & 4.964 & 868 & 20 & 2.304 & 1009 & 27 & 2.676 \\
Total & 31362 & 1359 & 4.333 & 66565 & 1314 & 1.974 & 97927 & 2673 & 2.729 \\
\hline
\end{tabular}


* Scinde province lying in a valley between India and Afghanistan (now in modern Pakistan) had been conquered by the British in 1843 following an attack on the British residency in Hyderabad by Baluch natives. The British general in command Sir Charles Napier, a Company officer stated, "We have no right to seize Scinde, yet we shall do so, and a very advantageous, useful humane piece of rascality it will be" (Duncan and Walton 1991:37). This campaign was a remarkable example of military leadership as Napier's force of 5000 was heavily outnumbered by 60000 well armed Baluchis, but nonetheless he won two major battles at Miani, and at Hyderabad in 1843. At the conclusion of the campaign he despatched his famous one Latin word message to the Governor General of India, "Peccavi", translated as "I have sinned" (Dupuy and Dupuy 1999: 862).

\subsection{Sykes Interpretation of the Statistics: the Equation of Life}

The statistical analysis clearly demonstrates the un-healthiness of having to serve in Scinde province and how this significantly distorted the overall mortality rates. Sykes attempted to correct this irregularity through statistical adjustment,

"... in order to arrive at the true mortality of the Native army of Bombay exclusive of those in Scinde, some correction will be necessary. During 1844 the average strength of the regiments actually out of Scinde was 25625 and the deaths 566 or about 2.248 per cent. If this be deducted the six regiments returned from Scinde in the year preceding, the main strength of the residue will be 19708 , the deaths 328, giving a reduced mortality of 1.664 per cent. So that the influence of the regiments returned from Scinde was to increase the rate of mortality by during the year, .584 per cent.... It will be necessary to deduct from the results .584 percent... the mortality... will only be 1.390 per cent: approaching nearly to the mortality for Ireland and Sweden."

(Sykes 1847:119)

It was from these preceding and other tables that Sykes with Neison drew up three further tables or statistical modelling that he labelled the 'Equation of Life' although the intermediary process of calculation is not made explicit (Tables 3, 4 and 5). The tables reflected a comparative view of the value of life in various sections of the Bombay army from 1842-1844 at various ages, or the term of years for which there was an equal, two to one and a three to one probability of surviving. In addition he benchmarked these results against those of England and Wales and Glasgow and some other military units. These figures marked *are referred to by Sykes as the Northampton tables without explanation as he assumed any reader would be familiar with these. These were the Northampton Table of Mortality constructed by a Dr.Price first published in 1771 and based on flawed empirical evidence of births and deaths in two parishes in the town of Northampton. They were distinguished by being the first tables in widespread use by insurance companies for calculating pension annuities even though it had overestimated the levels of the death rate (Rothschild, 2009:777).

Table 3. The Equation of Life, Representing a Term of Years, for which there is an Equal Probability of Living

\begin{tabular}{cccccc}
\hline Ages & $\begin{array}{c}\text { Serving in Scinde } \\
\text { Province years }\end{array}$ & Residue & $\begin{array}{c}\text { Total Bombay } \\
\text { Army years }\end{array}$ & $\begin{array}{c}\text { England and } \\
\text { Wales-Males Years* }\end{array}$ & $\begin{array}{c}\text { Glasgow-Males } \\
\text { Years* }\end{array}$ \\
\hline 21 & 16.477 & 30.697 & 24.534 & 43.410 & 29.423 \\
25 & 16.100 & & 23.635 & 40.308 & 27.760 \\
30 & 15.278 & & 22.717 & 36.487 & 24.644 \\
35 & 14.409 & & & 32.635 & 21.743 \\
40 & & & 28.787 & 19.007 \\
45 & & & 24.978 & 16.363 \\
\hline
\end{tabular}

(Sykes 1847:131)

The above table indicated that a soldier at the age of 21 had an equal chance of surviving a further 24.534 years for the whole army but only 16.447 years if based in Scinde but those lucky to avoid service there had an equal chance of surviving to 30.697 years. This interpretative process was then applied in tables 4 and 5 .

Table 4. The Equation of Life, Representing a Term of Years, for which the Probability of Living is Two to One

\begin{tabular}{cccccc}
\hline Ages & $\begin{array}{c}\text { Serving in Scinde } \\
\text { Province }\end{array}$ & Residue & $\begin{array}{c}\text { Total Bombay } \\
\text { Army }\end{array}$ & $\begin{array}{c}\text { England and Wales- } \\
\text { Males* }\end{array}$ & $\begin{array}{c}\text { Glasgow - } \\
\text { Males* }\end{array}$ \\
\hline 21 & 9.479 & 20.563 & 14.771 & 32.913 & 21.595 \\
25 & 9.876 & 19.861 & 14.483 & 30.570 & 19.443 \\
30 & 9.484 & 18.247 & 14.307 & 27.669 & 16.969 \\
35 & 8.586 & 16.391 & 13.434 & 24.731 & 14.819 \\
40 & 8.230 & $\ldots$ & 12.393 & 21.679 & 12.696 \\
45 & $\ldots$ & $\ldots$ & $\ldots$ & 18.616 & 10.933 \\
\hline
\end{tabular}

(Sykes 1847:131) 
Table 5. The Equation of Life, Representing a Term of Years, for which the Probability of Living is Three to One

\begin{tabular}{cccccc}
\hline Ages & $\begin{array}{c}\text { Serving in Scinde } \\
\text { Province }\end{array}$ & Residue & $\begin{array}{c}\text { Total Bombay } \\
\text { Army }\end{array}$ & $\begin{array}{c}\text { England and Wales }- \\
\text { Males* }\end{array}$ & $\begin{array}{c}\text { Glasgow - } \\
\text { Males* }\end{array}$ \\
\hline 21 & 6.786 & 14.601 & 10.387 & 26.043 & 16.913 \\
25 & 6.770 & 14.661 & 10.251 & 24.267 & 15.102 \\
30 & 7.070 & 14.071 & 10.405 & 22.127 & 13.046 \\
35 & 6.211 & 12.735 & 9.919 & 19.827 & 11.231 \\
40 & 5.728 & 10.653 & 9.058 & 17.375 & 9.591 \\
45 & 7.000 & $\ldots$ & $\ldots$ & 14.875 & 8.169 \\
\hline
\end{tabular}

(Sykes 1847:131)

The analysis clearly showed the perils facing survival if posted for service in Scinde whereby the value of life was about half of that compared to service elsewhere.

\subsection{Extended Benchmarking of Mortality Rates}

In a further attempt at benchmarking for context placed in a concluding table the mortality Crown troops and other nation's rates of mortality noting that this on many occasions proved most favourable (Table 6). These were from the earlier work of Colonel Alexander Tulloch who was a pioneer medical statistics researcher into soldiers' welfare. He had presented a paper before the London Statistical Society in 1838 that had dealt with the general conditions appertaining to the health and fitness of the British military garrisons in the West Indies (Butterfield, 1981). Therefore, Tulloch who has been described as "one of the leading lights of the statistical movement of the early Victorian period" (Cookson, 2010:60), would probably have known Sykes personally and both would have been aware of each other's work.

Table 6. Mortality among the Military in Various Countries

\begin{tabular}{lc}
\hline & Mortality Per Cent \\
\hline British Dragoon Guards and Dragoons & 1.53 \\
British Foot Guards & 2.16 \\
British House Cavalry & 1.45 \\
British troops in Ireland & 1.55 \\
French Army & 1.95 \\
Prussian Army & 1.17 \\
British troops Gibraltar & 2.2 \\
Black troops (West Indies) & 6.2 \\
British troops, Malta & 1.87 \\
British troops, Ionian Islands & 2.83 \\
British troops Cape of Good Hope & 1.55 \\
British troops, Canada & 2.00 \\
\hline
\end{tabular}

(Sykes 1847:131)

\section{Cui Bono? (Who stands to gain?)}

\subsection{Arguing for Native Premiums and Private Pensions}

Sykes it will be recalled saw any form of work of mental labour if not guided towards some practical objective as a labour lost. In this case he used his findings to argue that the statistics of the Bombay army should provide for a complete revolution in opinion to the value of Native life in India. He argued that these statistics provided positive data for private life insurers that could be used as the basis for the introduction of life insurance at very low premiums amongst the Natives of India where hardly any existed at the time because of the exaction of high premiums. His arguments based on factual detail also argued on a moral base stating that, "If the publication and diffusion of these mortality returns should occasion an extension of the system of life assurance amongst the Natives, it would confer a blessing upon that portion of the community who have their salaries only as servants of the State, or of mercantile establishments, as a means of support and providing for their families" (Sykes 1847:118). The wider diffusion of these tables he argued could occasion an extension of life insurance amongst Indians as a means of support and providing for their families An example of existing specimen premium rates can be gleaned from an advert in the East India Register of 1847 (Table 7). 
Table 7. Specimen Rates Church of England Life and Fire Assurance Institution 1847

\begin{tabular}{ccccc}
\hline Age & $\begin{array}{c}\text { Civil } \\
\text { Seven Years }\end{array}$ & Life & $\begin{array}{c}\text { Military } \\
\text { Seven Years }\end{array}$ & Life \\
\hline 25 & Rs28 & Rs38 & Rs37 & Rs45 \\
30 & Rs31 & Rs42 & Rs39 & Rs49 \\
35 & Rs34 & Rs47 & Rs43 & Rs53 \\
40 & Rs38 & Rs53 & Rs47 & Rs59 \\
\hline
\end{tabular}

(Clark, 1847)

Equating 10 rupees to $£ 1$ sterling demonstrated how unaffordable this type of premium would render it beyond the reach of most Native soldiers and civilians.

The East India Register carried other insurance advertisements including the Universal Life Assurance Company, the Naval, Military, East India and General Life and Assurance Society which although based in London but had branches in Calcutta, Madras and Bombay, and it is likely that it was these societies that Sykes was inviting to provide insurance for the Indian soldiers and their dependants.

Thus, Sykes was advocating the introduction of regular and realistic savings levels for Indians towards their retirement based on rational calculation that would be attractive for the private insurance societies. This was justified by Sykes because of the Indians' superior diet and living habits compared to Europeans. Again there is no evidence to indicate that these private societies were convinced to offer the Indian Company employees these facilities. Finally, the demise of the Company Armies lay in the immediate future as a consequence of the widespread Indian Mutiny by many Native soldiers in 1858 when in the aftermath the British government took direct control of Indian affairs and most of the Company's Native and some European units were transferred to the government's establishment and pension regime (Endnote 2).

\section{Conclusion}

\subsection{The Statistics Summarised in Philosophical Context}

The paper has demonstrated that Sykes work was part of an innovative and wider European phenomenon of data collection to construct tables of facts that imparted knowledge via statistics of the surrounding world. In this instance it provided reliable mortality tables for insurance actuaries to utilise for calculating premiums and risk on a more dependable base than existing methods. According to the French philosopher Foucault these new knowledge systems could be used as a disciplinary mechanism of surveillance to maintain social disciplines. The first required constitution of tableaux vivants, i.e. the mortality tables which could transform the disorganised and dangerous multitudes into ordered multiplicities. This necessitated that,

“The drawing up of 'tables' was one of the great problems of the scientific, political and economic technology of the eighteenth century ... construct at the same time rational classifications of living beings... and thus build up an economic table".

(Foucault 1991:148)

Undoubtedly the mortality tables were rational economic tables. As an influential member of the statistical movement Sykes produced numerous tables for analysis and interpretation. These were used to support reasoned arguments in this case regarding the health and mortality risks of the Indian soldiers of the East India Company. This was offered as proof that the Indian soldiers were equally if not more healthy than other troops and thus, at less risk and worthy of being suitable for private pensions justified by his tables of the "Equation of Life". Although a utilitarian Sykes could also feel compassion for the well being of his former troops but it appears his aspirations were never realised.

\section{References}

Bacaër, N. (2011). A short History of Mathematical Population Dynamics, Springer-Verlag London Ltd, pp. 5-9. http://dx.doi.org/10.1007/978-0-85729-115-8_2

Bhimani, A. (1993). Indeterminacy and the Specificity of Accounting Change: Renault 1898-1938, Accounting Organizations and Society, 18(1), 1-139. http://dx.doi.org/10.1016/0361-3682(93)90023-Y

Boyle, D. (2000). The Tyranny of Numbers, London, Flamingo.

Brereton, J. M. (1986). The British Soldier: A Social History from 1661 to the Present Day, London, The Bodley Head. 
Butterfield, P. H. (1981). Sykes and Tulloch - Pioneer Researches into Sickness and Mortality Rates amongst British Army Personnel in the mid Nineteenth Century, Military History Journal, South African Military History Society, 5(4).

Cardew, A. (1929). The White Mutiny-A Forgotten episode in the history of the Indian Army, London, Constable \& Co Ltd.

Clarke, F. (1847). The East-India Register and Army List for 1847, $2^{\text {nd }}$ Ed, London, Wm H Allen \& Co.

Cookson, J. E. (2010). Alexander Tulloch and the Chelsea Out-Pensioners, Centralisation in the Early Victorian State, English Historical Review, CXXV(512), 60-82. http://dx.doi.org/10.1093/ehr/cep409

Cullen, M. J. (1975). The Statistical Movement in Early Victorian Britain. The Foundations of Empirical Social Research, Hassocks, Brighton, The Harvester Press Limited.

Drolet, M. (2004). History of European Ideas, Tocqueville's interest in the social: Or how statistics informed his 'new science of politics'. History of European Ideas, 31, 451-471. http://dx.doi.org/10.1016/j.histeuroideas.2004.11.005

Duncan, J., \& Walton, J. (1991). Heroes for Victoria Tunbridge Wells, Spellmount Ltd.

Dupuy, R. E., \& Dupuy, T. N. (1993). The Collins Encyclopaedia of Military History, $4^{\text {th }}$ Ed, London, BCA, Harper Collins, pp. 859-861.

Foucault, M. (1991). Discipline and Punish The Birth of the Prison, London, Penguin.

Freedgood, E. (2000). Victorian Writing About Risk, Cambridge Studies in Nineteenth Century Literature and Culture, 28, Cambridge University Press. http://dx.doi.org/10.1017/CBO9780511484797

Gourvish, T. R. (1972). Mark Huish and the London and North Western Railway, Leicester University Press.

Joukovsky, N. A. (2000). George and Mary Meredith, the East India Company, and the society of arts: new light on the author's early career, Studies in Philology, 97(4), 473-494.

MacKenzie, D. A. (1981). Statistics in Britain 1865-1930, Edinburgh University Press.

McCormick, T. (2009). Alchemy in the political arithmetic of Sir William Petty (1623-1687). Studies in History of Philosophy and Science Part A, 37(2), 290-307. http://dx.doi.org/10.1016/j.shpsa.2005.07.012

Micklethwait, J., \& Wooldridge, A. (2003). The Company A Short History of a Revolutionary Idea, London, Weidenfeld and Nicolson.

Misra, B. B. (1959). The Central Administration of the East India Company, Manchester University Press.

Mokyr, J., \& O'Grada. (1996). Height and Health in the United Kingdom, 1815-1860: Evidence from the East India Company. Explorations in Economic History, 33, 141-167. http://dx.doi.org/10.1006/exeh.1996.0007

O'Brien, C. (2011). The origins and originators of early statistical societies: a comparison of Liverpool and Manchester. Journal of the Royal Statistical Society, 174(1), 51-62. http://dx.doi.org/10.1111/j.1467-985X.2010.00649.x

O'Malley, L. S. S. (1931). The Indian Civil Service, 1601-1930, London, John Murray.

Rothschild, C. G. (2009). Adverse selection in annuity markets: Evidence from the British Life Annuity Act of 1808. Journal of Public Economics, 93, 776-784. http://dx.doi.org/10.1016/j.jpubeco.2009.01.002

Smith, E., \& Co. (1885). Dictionary of National Biography, 55, 258.

Sykes, H. (1847). Vital Statistics of the East India Company's Armies in India, European and Native. Journal of the Statistical Society of London, 10(2), 100-131. http://dx.doi.org/10.2307/2337686

Talbot, P. A. (2005). Colonel W H Sykes Statistician; Costing the British and French Armies of 1864. South African Military History Society. Military History Journal, 13(4), 148-153.

Talbot, P. A. (2008). The Health of John Company Armies, 1825-1845, A Statistical Accounting Analysis, South African Military History Society. Military History Journal, 14(4), 138-144..

Talbot, P. A. (2010). Colonel William Henry Sykes: his contribution to Statistical Accounting. Accounting History, 15(2), 1-24. http://dx.doi.org/10.1177/1032373209359332

Wild, A. (1999). The East India Company Trade and Conquest from 1600, London, Harper Collins. 


\section{Notes}

1. Special thanks are extended to Aberdeen University Library (Historical Manuscripts) who provided a photocopy of Sykes original paper.

2. The transference of the European soldiers to the Crown's army did not proceed smoothly. Its ultimate demise reflected the long tradition of ill discipline amongst the European forces in both the officer corps and ranks. In 1858 the transfer of Company troops to the Crown provoked another "White Mutiny" with a strike by the Madras Fusiliers, $1^{\text {st }}$ Bengal Cavalry and other units who objected to being unilaterally transferred to the Crown's Army. The mutiny gave rise to strong expressions of anti-crown sentiments that culminated in the worst excess by the $5^{\text {th }}$ Bengal European cavalry barricading themselves in their barracks and abusing their officers. Regular Army infantry and artillery surrounded the mutineers who after a week were starved into submission. Although in the aftermath the government once again attempted to gloss over the incident by acquiescing to most of the troop's demands only 2809 troops elected to transfer to the Crown Army and 10116 were transported back to Britain and the troublesome $5^{\text {th }}$ Bengal European cavalry later mutinied once again. The authorities proved less lenient this second time and the mutiny was quickly subdued by a demonstration of force followed by courts martial. The ringleaders of the mutiny were discharged and sentenced to penal servitude but the leading mutineer, Private William Johnson was executed by firing squad in 1860 (Brereton, 1986:81-82). Native regiments apart from the mutinous regiments which were disbanded were successfully incorporated into the Crown's forces.

\section{(cc) BY}

This work is licensed under a Creative Commons Attribution 3.0 License. 